\title{
Accounting
}

\section{The effect of accounting information system on corporate governance}

\author{
Kayed Ab Allah Al-Attar ${ }^{\text {* }}$
}

\begin{tabular}{l}
${ }^{a}$ Faculty of Business, Al-Isra University \\
\hline C H R O N I C L E \\
\hline Article history: \\
Received: September 2, 2020 \\
Received in revised format: \\
September 302020 \\
Accepted: October 8, 2020 \\
Available online: \\
October 8, 2020 \\
\hline Keywords: \\
AIS Applications \\
Quality of Accounting Information \\
Corporate Governance \\
Accounting Governance
\end{tabular}

\begin{abstract}
A B S T R A C T
In this study, (72) financial managers and managers of the accounting department within the pharmaceutical industry in Jordan during the fiscal year 2019-2020 were exposed to a questionnaire in order to examine the influence of AIS applications on the outcomes of accounting corporate governance. Researcher adopted accounting governance variables from different studies and included Control, Commitment to Accounting Standards, Performance Evaluation and Add Confidence and Credibility to the survey. Results of study indicated an influence of all given variables of accounting governance on the outcomes of corporate governance which is attributed to the quality of accounting information and making sure that all information given are based on the standards of accounting. Some recommendations were presented with the study later on.
\end{abstract}

(C) 2021 by the authors; licensee Growing Science, Canada

\section{Introduction}

The financial and business world has witnessed, for some time, a number of transformations and changes as results of financial and economic crises, which rocked many economies, especially developed ones. It has resulted in the realization of some giant companies such as Enron, Worldcom, Parmalat, Lernout \& Hausp, for large financial losses, not because of illegal activities but because of how they showed their financial positions. Since companies are registered and deal in the financial markets; they tried to show financial conditions to reflect the truth, which led to a loss of confidence in them as well as in the financial markets, which led to the departure of investors from them (Honggowati et al., 2017). Such results have been accompanied by a loss of confidence in the information or accounting information included in the financial statements. The latter, which was prepared in a way that did not show the reality of the financial conditions of economic institutions, and has resulted in the loss of accounting information for one of its distinguishing factors, which is the quality factor.

In this paper, we study the effect of accounting information system on accounting dimensions of corporate governance, including control, commitment to accounting standards, performance evaluation and confidence and credibility.

Fig. 1 shows the proposed study of this paper.

\footnotetext{
* Corresponding author.

E-mail address: kayed.alattar@iu.edu.jo (K. A. A. Al-Attar) 


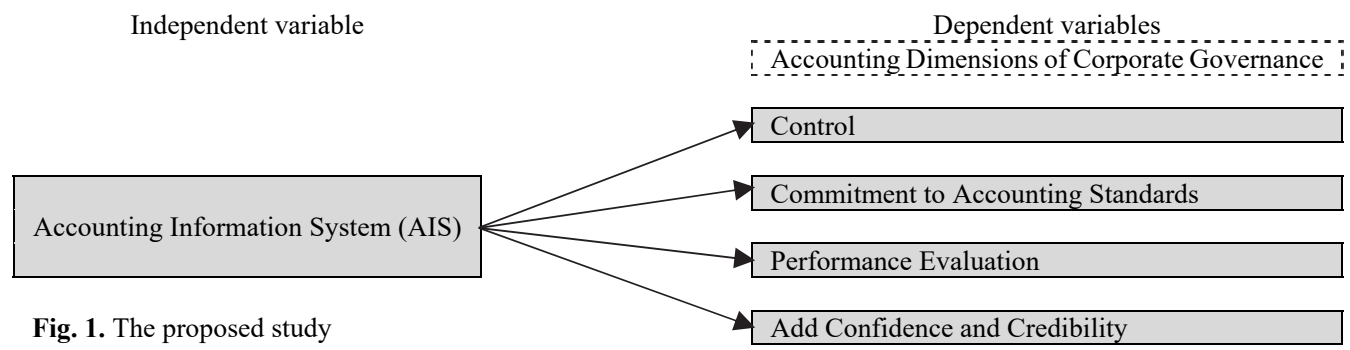

From Fig. 1, we proposed the following set of hypotheses:

\section{Main hypothesis:}

$\mathrm{H}$ : There is a statistical influence of AIS on corporate governance outcomes within Jordanian pharmaceutical sector.

Mashkour and Abbas (2018) emphasize the idea of the relationship between governance and accounting information systems, provided that this relationship is mutually beneficial. From his point of view, author believes that accounting information systems affect the outputs of governance by controlling the imbalances that would arise during the accounting processes carried out by the organization and which they adopt for disclosure, as they are committed to the principles of governance. Hence, accounting information systems are required to address the primary foundations on which the various governance standards are based. As for Uyar et al. (2017), emphasized that the outputs of accounting information systems provide accounting information based on the credibility, objectivity, integrity, and accuracy of financial reports, which leads to ensuring a high level of governance by focusing on its fundamentals, principles and mechanisms.

Based on the argument above, following sub-hypotheses were developed:

\section{Sub-Hypotheses:}

$\mathrm{H}_{\mathrm{a}}$ : There is a statistical influence of AIS on controlling corporate governance outcomes within Jordanian pharmaceutical sector.

$\mathrm{H}_{\mathbf{b}}$ : There is a statistical influence of AIS on commitment to accounting standards within corporate governance outcomes within Jordanian pharmaceutical sector.

$\mathrm{H}_{\mathrm{c}}$ : There is a statistical influence of AIS on performance evaluation within corporate governance outcomes within Jordanian pharmaceutical sector.

$\mathrm{H}_{\mathrm{d}}$ : There is a statistical influence of AIS on adding confidence and credibility to corporate governance outcomes within Jordanian pharmaceutical sector.

The above variables were chosen to resemble the main variables of study due to their suitability to the nature of the study and the suitability to the setting of research. From that point, and based on above development of hypotheses, the current study aimed at examining the influence of AIS applications on outcomes of corporate governance from perspective of financial managers and managers of the accounting department within the pharmaceutical industry in Jordan during the fiscal year 20192020 .

\section{Literature Review}

\subsection{Accounting Information System (AIS)}

Curtis (1995) identifies AIS as the sub system of information within an enterprise. According to Curtis (1995), AIS serves the purpose of accumulating information from various subsystems within an entity by relaying it to the information processing subsystem of the organization. According to Kadous et al. (2012), AIS is an approach used in accounting to assist in management planning, control and monitoring of the economic activities of an organization. This integrated system focuses on certain objectives and is useful in decision making. As reinforced by Louadi (1998), AIS provides decision makers with useful information that helps in decision making. Louadi (1998) further noted that AIS is a management information system and that it aids in collecting, analyzing, classifying, storing and providing useful financial information to management bodies for purposes of decision making. For others, AIS is a system encompassing a combination of accounting techniques, methodologies, 
and controls and ICT, and one used for tracking transactions, external reporting of data, reporting of internal data, and for trend analysis and financial statements reporting.

Others researchers (e.g., Borthick \& Clark, 1990; Wilkinson et al., 2000) acknowledge that AISs is a vital system as it aids in effective decision making. For Wilkinson (1993), AIS is a useful system in managing strategic priorities and in strategic management. Supporting this view, Rankin et al. (2012) observed that AIS facilitates effective decision making by faithfully representing relevant accounting information. Rankin et al. (2012) further clarified that relevance of information denotes economic constructs (e.g., historical cost, fair value) that assist in decision making. Romney and Steinbart (2006) also contented that AIS can give an organization a strategic advantage. Romney and Steinbart (2006) highlighted six interrelated components of AIS that can give an organization a strategic advantage: procedures and instructions, people, information technology infrastructure, data, security measures and internal controls, and software.

\subsection{Uses of AIS Applications}

Traditionally, AIS was limited to financial information. The focus of this system was on collecting, analyzing, processing and communicating accounting information to tax agencies, bankers, investors, creditors, owners, the management, and other internal parties. However, today, AIS deals with both non-financial and financial information. As indicated by Louadi (1998) and Paulo et al. (2013), the key function of AIS is assigning quantitative value of the present, past and future business events. Other functions of AIS include data control, data collection and maintenance, and information generation. When used in combination with computerized accounting system, AIS can reveal the profit financial statements, Balance Sheet and cash flow statement. AIS can also process and transform data into accounting information. On this basis, AIS can be used by external users, internal users, and other users during the output, processing and input stages (Bukenya, 2014). Vendors (e.g., Oracle, SAP, and Microsoft) sell AIS as prebuilt software packages. In this way, one can customized this software according to the business processes or need. Researchers claimed that success of strategic advantage is an outcome of well managed Accounting Information Systems (AIS) (Langfield-Smith, 1997).

\subsection{Quality of Accounting Information}

The quality of accounting information is the characteristics of accounting information or the rules that must be adopted in order to assess the level of quality of accounting information so that determining the set of characteristics related to accounting information will help those in charge of setting accounting standards, as well as assisting officials when preparing financial statements in evaluating accounting information (Komala, 2012). Mamić Sačer and Oluić (2013) and Susanto (2017) noted that financial accounting is based on creating and collecting useful information for investors, creditors and decision makers, in order to use it in investment and credit decisions, as generally accepted accounting principles require that financial information be understood by the people who will use it. For its users, the quality characteristics of accounting information are distinguished by:

\subsection{Relevance}

Wisna (2015) sated that the usefulness of financial information appears during the decision-making process, so this information is bound to relate to the decisions of end-users, as other information cannot be used, and it must work to exclude them from the financial statements unless they will affect the future decisions of investors or lenders, so This information must possess the quality characteristics of the accounting-related accounting information, which must possess three main characteristics: predictive value, feedback, and timing.

\subsection{Reliability}

It is used in order to compare the company's performance from one year to another and also compare it with competitors, and therefore this financial information must be prepared in a similar way in order to allow the ability to compare, because with its difference it cannot be compared to other data, and also the matter with respect to the currency, where it cannot be compared The financial statements are presented in different currencies in nominal terms, but must be converted into the same currency in order to compare them in a beneficial way (Iskandar, 2015).

\subsection{Consistency}

Kao (2014) saw that one of the characteristics of the quality of accounting information is its consistency, which is intended to necessitate the use of the same accounting methods in recording similar transactions, i.e. the use of accounting methods consistently and by following the same accounting rules that are used in the processing of financial data, and consistency applies to the characteristics of the quality of accounting information due to its ability to provide an understanding of the data Finance 
as well as the ability to process it, which in turn provides the possibility to compare financial statements in different years, and it is possible to change the means of processing financial statements, but when they are acceptable and have clear justifications.

\subsection{Corporate Governance}

There is no general agreement on a single concept or definition of corporate or corporate governance. Rather, there are multiple concepts that have multiple directions and specialization for those who dealt with this topic in study and research (Dănescu et al, 2015). Previous studies have focused, and for a long time, on traditional approaches to address this issue, the shareholders' entrance, which is concerned with ensuring shareholders' rights and working to maximize them, which is mainly profitability, and the entrance of the parties involved in the company (managers, clients, workers, creditors, etc.) who is concerned with ensuring and achieving the interests of these people. However, the trend at the present time is towards modern approaches to corporate governance based on knowledge and competencies (Brown et al., 2011).

The general concept of the word "governance", that is, "to govern", after the word has moved from politics to management and the economy, and its association with organizations and companies has become indicative of the terminological meaning to be made up of two parts which are "corporate governance" or sometimes it is called "Good governance" and they carry the same connotation, but the latter, as it is said, refers to the scientific term for governance (Carcello \& Hermanson, 2011).

According to Agrawal and Cooper (2017), corporate governance refers to the set of structures and processes necessary to direct and control the institution, define and distribute rights and duties among the main participants in the institutions and ensure the understanding of shareholders, members of the board of directors and managers thereof, as well as define rules and procedures for making decisions about the company's order.

As for Ahmed and Henry (2012), corporate governance was defined as a group of relationships among those in charge of the company's management, board of directors, shareholders and other shareholders. From the perspective of Peters and Romi (2014), it was defined as operations carried out through the procedures used by representatives of stakeholders in order to provide supervision of risk management, monitoring the risks of the economic unit and emphasizing the adequacy of controls to accomplish goals and preserve the values of the facility.

On the other hand, Cong and Freedman (2011) defined corporate governance as the system by which companies are managed and monitored while Caskey and Laux (2017) defined it as a set of responsibilities and practices carried out by the Board of Directors and Executive Management (Governance Authority) with the goal of (providing strategic direction, ensuring that goals are achieved, ensuring that risks are properly managed, and verifying the responsible use of the facility) as it reflects this definition is a side of performance and a commitment to governance.

\subsection{Dimensions of Corporate Governance}

According to Christensen et al. (2010), governance has two types of constituents (external constituents and internal constituents), and upon them it depends on determining the quality and maturity that can be achieved by the government in its application and practices. Magnan and Markarian (2011) stated that external elements are based on the investment climate of the state, which includes on several aspects the most important of which are the legislative environment and the legal and regulatory ground through which investment is practiced through such as (the litigation system, the corporate system, the trade and investment system, the anti-commercial fraud system, the bankruptcy system, the competition protection system, and others related laws and regulations). Zimmermann and Werner (2013) added that external constituents is the efficiency of the financial industry and means (banks, the money market and finance) as well as the efficiency of the supervisory bodies (such as the Capital Market Authority or as it is called in other functions, and the certified accountants and accredited audit committees) in addition to organizations specialized in free professions such as law firms, credit rating and financial advisory firms, as the presence of these external components guarantees the integrity of the infrastructure and the rigidity of the ground that prepares the organizations by applying their governance model (Evans et al., 2011). As for internal constituents, Hancock et al. (2010) noted that it refers to the rules and foundations that define how decisions are made and the distribution of powers within the company between the General Assembly and the Board of Directors and the executives, whose availability on the one hand and their application on the other hand reduces the conflict between stakeholders. Speaking of the main dimensions of governance, Brown et al. (2011) stated that speaking of the basic principles of corporate governance, which guarantees an optimal application and raises its quality and maturity, is the availability of a set of principles that can be reviewed as follows:

Transparency: Board members must clearly explain to the owners of capital and major depositors the reason for making any fundamental decision.

Responsibility: The members of the board of directors must perform their duties professionally and professionally. 
Accountability: The members of the board of directors must be accountable for their decisions and accountable by the shareholders.

Justice: Since it must have all equitable shareholders of the members of the Board of Directors, and executive management in a fair manner.

\subsection{Standards of Corporate Governance}

In terms of the criteria established for governance, it has varied according to the reference that adopted that concept, according to the Organization for Economic Cooperation and Development (Carcello et al., 2011), the application of governance is based on six criteria: (1) ensuring that there is a basis for an effective framework for corporate governance, 2 / preserving the rights of all shareholders, 3 / transaction Equal among all shareholders, 4 / the role of stakeholders in the methods of exercising management powers of the company, 5 / disclosure and transparency, 6 / responsibilities of the board of directors). While the Basel Committee, which is supervised by the Bank for International Settlements (BIS), met seven standards of governance:

- Company values and honorable covenants for sound behavior

- $\quad$ Preparing a firm strategy for the company

- $\quad$ Proper balance of responsibilities and decision-making centers

- Establishing a mechanism for effective cooperation between the board of directors, auditors, and senior management

- Availability of a strong internal control system that includes audit tasks Internal and external risk management independent of business lines taking into account the suitability of the authorities with responsibilities

- Special monitoring of risk centers in locations where conflicts of interest escalate, including working relationships with borrowers associated with the bank and major shareholders and senior management, or major decision-makers in the organization

- Financial and administrative incentives for senior management that achieve work in a proper manner

Whereas, the International Finance Corporation (IFC) standards

- $\quad$ Accepted good governance practices

- $\quad$ Additional steps to ensure a new good judgment

- Essential contributions to improving good governance locally

- $\quad$ Leadership

\subsection{Goals of Corporate Governance}

Governance goals can be summarized as a guarantor platform for achieving justice, transparency and ensuring the right to accountability (Wilkin \& Chenhall, 2010), and a source of protection for the rights of shareholders, whether they are a minority or a majority (Baber et al., 2013). Leventis et al. (2013) noted that governance ensures that there is a distribution of roles and responsibilities across tight organizational structures that enable accountability and accountability, and enables impartial and independent oversight to perform its roles without influence, bias or pressure, in addition to that it is an effective tool for spreading a culture of justice in treatment and dealing that reassures all stakeholders, in addition to its contribution to preparing the way for resorting to the judiciary in the event of any breach that may arise while ensuring the preservation of rights, and ensuring the ability of shareholders to exercise their authority to interfere in the emergence of problems in a way that guarantees them their rights (Grossi et al., 2014).

\subsection{The relationship between AIS Applications and Corporate Governance}

\section{Bookkeeping}

As argued by Nobes and Stadler (2013), double-entry bookkeeping is concerned with recording of financial transactions. This process plays a crucial role in financial reporting and accounting practices as it helps managers to classify and organize business transactions. Data from this process is used in accounting applications. According to Pallisserry (2012) any mistake committed during book-keeping may have a domino effect on various financial processes. On this ground, bookkeeping practices influence the reliability of financial reporting. Inappropriate recording by bookkeepers can lead to false financial statements. False financial statement may lead to poor external and internal decision making.

It is worth noting that as computerized systems, AIS make use of software making accounting job easier. This is achieved by compiling payroll, tax and financial data. AIS can also execute other bookkeeping functions. Unlike the manual bookkeeping system, AIS can be operated easily. It accumulates and stores data. On this basis, the effective use of AIS for bookkeeping purpose impacts positively to corporate governance. 
Corporate or financial reporting largely dependents on AIS, and as noted by Abraham et al. (2008) increasing need for organizations to undertake financial reporting has led to increased demand for non-financial and financial information. Abraham et al. (2008) observed that AIS helps in tracking accounting activity, and that the resulting this system yields financial reports that are needed by the organization's management and other interested parties (e.g., creditors, tax authorizes, and investors) to make informed decisions. According to Zhai and Wang (2016), AIS facilitates effective corporate governance by presenting information concerning financial performance, a company's cash flow relating to specific period or date, changes in the equity of stockholders, and financial position of a firm. Financial reports are often prepared in line with the financial reporting standards and accounting principles to facilitate comparison across various industries and companies as well as across years. Directors are tasked with dissemination information regarding the company's financial position to investors. Directors also supervise, monitor, and oversee financial reporting. However, corporate failure may occur because of the failure of a company to have in place reliable systems such as AIS (Pallisserry, 2012). Pallisserry (2012) observed that the reliability and usefulness of financial reports can be compromised if the company lacks robust systems such as AIS. According to Abraham et al. (2008), AIS ensures objectivity and reliability of financial reports eliminating possible errors due to subjectivity. Supporting this view, Bolon (1998) advanced that lack of a robust financial reporting system, and deficiency in individuals involved in monitoring and preparing financial reports (e.g., accounting personnel and board members), and deficiency in regulatory system and nature of accounting standards may lead to unreliable financial reports. Bolon (1998) further emphasized the importance of AIS noting that corporate governance can be improved by having in place AIS that improves the quality of financial information reflected in financial reports. In furtherance of this argument, Ponemon and Nagida (1990) held that well-structured AIS determines future steps in financial reporting, as well as assists in decision making. According to Ponemon and Nagida (1990), the AIS system helps users differentiate and better understand various scenarios. Previous studies recognized the importance of AIS in improving the corporate governance emphasizes its value in effective decision making (Hunton, 2002; Kılıç et al., 2014). For example, Kılıç et al. (2014) argued that AIS impacts on effective internal controls, performance evaluation, regular financial activities and decision making. Hunton (2002) sees AIS as the lifeblood of corporate governance noting that it determines the course of action of a business. Seal (2006) found a robust positive relationship between organizational effectiveness and accounting information system noting that for an organization to gain a competitive advantage and utilize its resources effectively, it must embrace datadriven decision making system.

In the extant literature advantage of using AIS and other financial or accounting systems by an enterprise include improved effectiveness, improved efficiency in auditing and financial reporting, greater reliability and transparency; enhanced comparability (Jones \& Finley, 2011; Dumontier \& Raffournier, 1998; Joshi \& Ramadhan, 2002; Jeanjean \& Stolowy, 2008; Ball, 2006; Neag et al., 2009Kılıç et al., 2014; Uyar \& Güngörmüş, 2013; Epstein \& Jermakowicz, 2007; Madawaki, 2012). Uyar and Güngörmüş (2013) tie these advantages to corporate governance mechanism as they play a role in good governance practices.

\section{Budgeting and AIS}

AIS are believed to contribute to good corporate government through improving budgeting and internal monitoring and reporting, and providing relevant and timely accounting information (Seal, 2006; Mayanja \& Van der Poll, 2011).

AISs recognize record and summarize events and report accounting information (Raliman \& Halladay, 1998). As opined by Raliman and Halladay (1998), these events constitute the flow of information. The flow of information in managerial accounting information systems occurs in two directions: a bottom-up information flow and a top-down information flow. In the former, information flow starts with the events that occur at the organization's lower levels. Responsibility reporting system records, processes and reports events to the executives at the higher level of the organization. In the later, information flow originates from events taking place at the top level of the management. These events are recorded in the system that report to lower-level employees. AISs offer a bottom-up information flow with events occurring at the lower level. These recorded events are summarized and reported to the organization's top management. The budgeting and responsibility systems provide this flow of information. The top-down information AIS yields periodic budgets. These budgets facilitate managers to have plants detailing the budgeting period. These budgets are useful in achieving organizational objectives. Often firms adopt systems that offer performance budgeting and responsibility reporting.

\section{Method}

In order to realize aim of study, researcher adopted the quantitative approach depending on utilizing a questionnaire which was distributed on (100) financial managers and managers of the accounting department within the pharmaceutical industry in Jordan during the fiscal year 2019-2020. The questionnaire contained two main sections (demographics of study sample, statements related to study variables). After application process researcher was able to retrieve (72) properly filled questionnaire which 
indicated a statistically accepted response ratio of $(72 \%)$. In order to examine the reliability of study tool; researcher used Cronbach Alpha which scored a value of $=0.933$ as an excellent ratio, being higher than the acceptable percentage 0.60 .

\section{Results and Discussion}

Following section presented results of study it included results of analyzing demographic data of sample who responded to questionnaire, in addition to analysis of questionnaire statements and variables, also hypotheses testing appeared at the end of the section. In Fig. 2 below, sample responded to the questionnaire was analyzed. It appeared that majority of sample was males forming (69.4\%) of total sample who held a degree of BA forming (73.6\%) of total sample and had an experience of (5-7 years) forming $(37.5 \%)$ of the sample; demographics regarding age was also calculated and it gave an indication that majority of sample was in a range of 31-36 years old forming (43.1\%) of total sample.

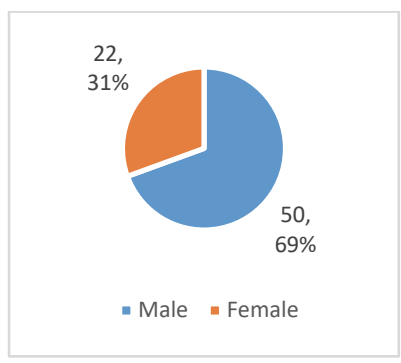

Gender

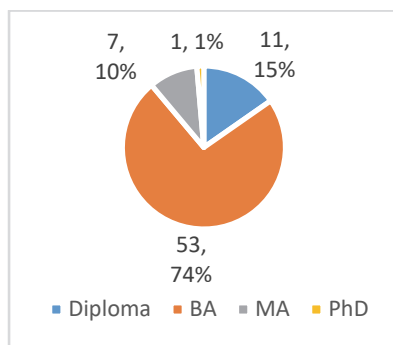

Educational background

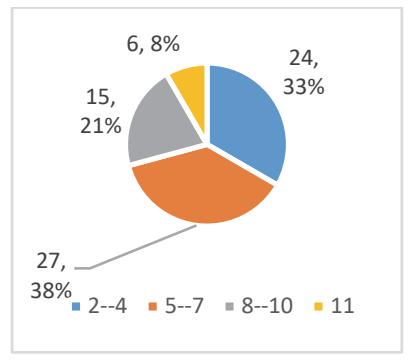

Job experience

Fig. 2. Personal characteristics of the participants

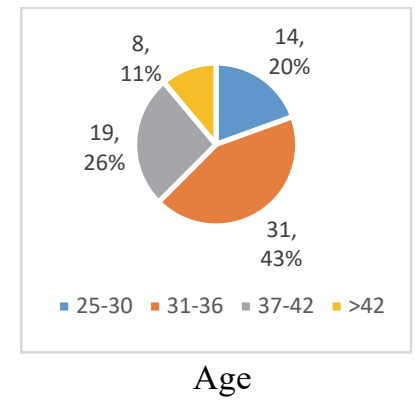

Age

Table 1 below showed results of questionnaire statements analysis as according to sample responses; it was seen that respondents held a positive attitude toward above statements as their means were greater than mean of the scale 3.00. On the other hand, the following descriptive statistics of variables indicated that that there was a positive attitude towards variable of study as their mean scored higher than mean of scale 3.00 which was seen to be a positive result.

Table 1

Descriptive information of the survey

\begin{tabular}{|c|c|c|c|c|c|}
\hline & $\mathrm{N}$ & Min & Max & Mean & $\begin{array}{l}\text { Std. } \\
\text { Dev. }\end{array}$ \\
\hline Accounting Information System & 72 & 1.00 & 5.00 & 3.1910 & .89747 \\
\hline AIS applications present valid info for organizations to use through its activities & 72 & 1 & 5 & 3.46 & 1.414 \\
\hline All data and information results from AIS applications are precise as long as the input data are accurate & 72 & 1 & 5 & 3.39 & 1.306 \\
\hline The accuracy of input data depends on the commitment of the organization with the governance aspects & 72 & 1 & 5 & 3.38 & 1.192 \\
\hline $\begin{array}{l}\text { AIS applications are required to be based on high tech devices in order to guarantee best and most suitable } \\
\text { governance }\end{array}$ & 72 & 1 & 5 & 3.36 & 1.225 \\
\hline $\begin{array}{l}\text { With dimensions of governance and accuracy of AIS results the organization can avoid many risks and failures on } \\
\text { both financial and non-financial levels }\end{array}$ & 72 & 1 & 5 & 3.33 & 1.175 \\
\hline \multicolumn{6}{|l|}{ Accounting Dimensions of Corporate Governance } \\
\hline Control & 72 & 1.00 & 5.00 & 3.1910 & .89747 \\
\hline Governance imposes control over accounting in two stages, pre and post & 72 & 1 & 5 & 3.19 & 1.194 \\
\hline AIS in CG supports full sharing of information for those who are related to the organization & 72 & 1 & 5 & 3.18 & .983 \\
\hline Through precise data AIS can control the decisions of the board to reach the best governance practice & 72 & 1 & 5 & 3.14 & .924 \\
\hline The relationship between AIS and corporate governance is bounded to the level of control applied on both sides & 72 & 1 & 5 & 3.25 & .931 \\
\hline Commitment to Accounting Standards & 72 & 1.00 & 5.00 & 3.3507 & .88280 \\
\hline Governance follows the actual application of accounting standards & 72 & 1 & 5 & 3.43 & .962 \\
\hline Through governance, there would be a follow up for performance, productivity and profit & 72 & 1 & 5 & 3.28 & 1.010 \\
\hline Governance imposes the necessity for disclosure & 72 & 1 & 5 & 3.33 & 1.021 \\
\hline Through governance, there is a prove of disclosure that appears in reports and financial listings & 72 & 1 & 5 & 3.36 & .983 \\
\hline Performance Evaluation & 72 & 1.00 & 5.00 & 3.2639 & 1.01041 \\
\hline With the accounting information reached through governance there is a chance to evaluate performance & 72 & 1 & 5 & 3.13 & 1.198 \\
\hline Managing performance through finances guarantees a good level of performance & 72 & 1 & 5 & 3.10 & 1.212 \\
\hline Governance is able to uncover any gaps in performance through AIS applications & 72 & 1 & 5 & 3.43 & 1.149 \\
\hline With governance, decision making can be done in accordance with AIS outcomes for the benefit of the organization & 72 & 1 & 5 & 3.40 & 1.057 \\
\hline Add Confidence and Credibility & 72 & 1.44 & 5.00 & 3.2951 & .73834 \\
\hline Depending on AIS, governance can result in more credible outcomes through monitoring the role external auditors & 72 & 1 & 5 & 3.35 & 1.077 \\
\hline AIS experience is one of corporate governance requirements & 72 & 1 & 5 & 3.32 & 1.032 \\
\hline Gathered with AIS applications, governance can present valid and dependable accounting information & 72 & 1 & 5 & 3.53 & .934 \\
\hline Governance that depends on AIS outcomes can predict failure and break outs of organizations & 72 & 1 & 5 & 3.31 & .914 \\
\hline
\end{tabular}


The main hypothesis of this survey investigates the effect of AIS on corporate governance outcomes. Table 2 shows the results of simple regression analysis.

Table 2

The summary of regression analysis for testing the main hypothesis

\begin{tabular}{|c|c|c|c|c|c|c|}
\hline \multirow{2}{*}{\multicolumn{2}{|c|}{ Model }} & \multicolumn{2}{|c|}{ Unstandardized Coefficients } & \multirow{2}{*}{$\begin{array}{c}\text { Standardized Coefficients } \\
\text { Beta }\end{array}$} & \multirow[b]{2}{*}{$\mathrm{t}$} & \multirow[b]{2}{*}{ Sig. } \\
\hline & & B & Std. Error & & & \\
\hline 1 & (Constant) & 2.165 & .258 & & 8.386 & .000 \\
\hline & AIS & .334 & .073 & .481 & 4.588 & .000 \\
\hline
\end{tabular}

F-value $=21.050(0.000) \mathrm{R}=0.481 \mathrm{R}$-Square $=0.231$ Adjusted R-Square $=0.22$

According to the results of Table 2, F-value is equal to 21.050, which is meaningful when the level of significance is one percent. This means there is a linear relationship between independent and dependent variable. In addition, $t$-values for both intercept and independent variable are statistically significant. The adjusted R-Square is equal to 0.481 which means the independent variable (AIS) can describe approximately $48 \%$ of the changes on corporate governance as dependent variable and finally the positive intercept indicates that a unit increase in AIS will have 0.334 unit increase on governance outcome.

\subsubsection{The first sub-hypothesis: The effect of AIS on controlling corporate governance outcomes}

The first sub-hypothesis of this survey studies the impact of AIS on control corporate governance outcomes. Table 3 demonstrates the results of simple regression analysis.

Table 3

The summary of regression analysis on the effect of AIS on controlling corporate governance outcomes

\begin{tabular}{|c|c|c|c|c|c|c|}
\hline \multirow[b]{2}{*}{ Model } & & \multicolumn{2}{|c|}{ Unstandardized Coefficients } & \multirow{2}{*}{$\begin{array}{c}\text { Standardized Coefficients } \\
\text { Beta }\end{array}$} & \multirow[b]{2}{*}{$\mathrm{t}$} & \multirow[b]{2}{*}{ Sig. } \\
\hline & & B & Std. Error & & & \\
\hline 1 & (Constant) & 1.664 & .302 & & 5.501 & .000 \\
\hline & AIS & .451 & .085 & .534 & 5.290 & .000 \\
\hline
\end{tabular}

$\mathrm{F}$-value $=27.986(0.000) \mathrm{R}=0.534 \mathrm{R}$-Square $=0.286$ Adjusted $\mathrm{R}$-Square $=0.275$

Based on the results of Table 3, F-value is equal to 27.986, which is meaningful when the level of significance is one percent. This means there is a linear relationship between independent and dependent variable. In addition, $t$-values for both intercept and independent variable are statistically significant. The adjusted R-Square is equal to 0.286 which indicates the independent variable (AIS) can describe approximately $29 \%$ of the changes on controlling corporate governance as dependent variable and finally the positive intercept indicates that a unit increase in AIS will have 0.451 unit increase on governance outcome.

4.1.2 The second sub-hypothesis: The effect of AIS on commitment to accounting standards within corporate governance outcomes

The second sub-hypothesis of this survey studies the impact of AIS on commitment to accounting standards within corporate governance outcomes. Table 4 presents the results of simple regression analysis.

\section{Table 4}

The summary of regression analysis on the effect of AIS on commitment to accounting standards within corporate governance outcomes

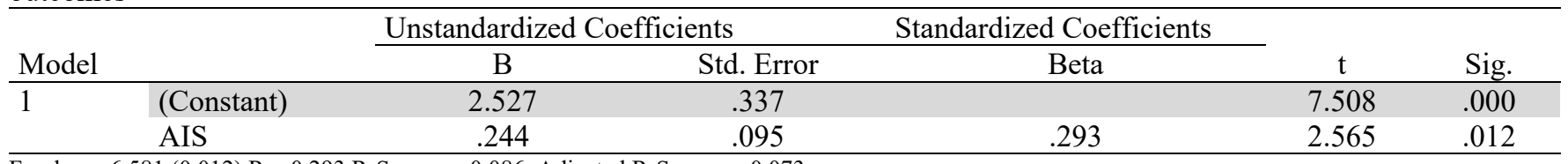

F-value $=6.581(0.012) \mathrm{R}=0.293 \mathrm{R}$-Square $=0.086$ Adjusted R-Square $=0.073$

Based on the results of Table 4, F-value is equal to 6.581, which is meaningful when the level of significance is five percent. This means there is a linear relationship between independent and dependent variable. In addition, $t$-values for both intercept and independent variable are statistically significant. The adjusted R-Square is equal to 0.073 which means the independent variable (AIS) can describe approximately $29 \%$ of the changes on commitment to accounting standards within corporate governance outcomes as dependent variable and finally the positive intercept indicates that a unit increase in AIS will have 0.244 unit increase on commitment to accounting standards within corporate governance outcomes. 
The third sub-hypothesis of this survey investigate the impact of AIS on performance evaluation within corporate governance outcomes. Table 5 shows the results of simple regression analysis.

Table 5

The summary of regression analysis on the effect of AIS on performance evaluation within corporate governance outcomes

\begin{tabular}{|c|c|c|c|c|c|c|}
\hline \multirow{2}{*}{\multicolumn{2}{|c|}{ Model }} & \multicolumn{2}{|c|}{ Unstandardized Coefficients } & \multirow{2}{*}{$\frac{\text { Standardized Coefficients }}{\text { Beta }}$} & \multirow[b]{2}{*}{$\mathrm{t}$} & \multirow[b]{2}{*}{ Sig. } \\
\hline & & B & Std. Error & & & \\
\hline 1 & (Constant) & 2.121 & .377 & & 5.633 & .000 \\
\hline & AIS & .338 & .106 & .355 & 3.178 & .002 \\
\hline
\end{tabular}

F-value $=10.102(0.002) \mathrm{R}=0.355 \mathrm{R}$-Square $=0.126$ Adjusted R-Square $=0.114$

Based on the results of Table 5, F-value is equal to 10.102, which is meaningful when the level of significance is one percent. This means there is a linear relationship between independent and dependent variable. In addition, t-values for both intercept and independent variable are statistically significant. The adjusted R-Square is equal to 0.126 which means the independent variable (AIS) can describe approximately $13 \%$ of the changes on commitment to accounting standards within corporate governance outcomes as dependent variable and finally the positive intercept indicates that a unit increase in AIS will have 0.338 unit increase on performance evaluation within corporate governance outcomes.

\subsubsection{The fourth sub-hypothesis: The effect of AIS on adding confidence and credibility to corporate governance outcomes}

The last sub-hypothesis of this survey investigates the impact of AIS on adding confidence and credibility to corporate governance outcomes. Table 6 gives the results of simple regression analysis.

Table 6

The summary of regression analysis on the effect of AIS on adding confidence and credibility to corporate governance outcomes

\begin{tabular}{|c|c|c|c|c|c|c|}
\hline \multirow[b]{2}{*}{ Model } & & \multicolumn{2}{|c|}{ Unstandardized Coefficients } & \multirow{2}{*}{$\begin{array}{c}\text { Standardized Coefficients } \\
\text { Beta }\end{array}$} & \multirow[b]{2}{*}{$\mathrm{t}$} & \multirow[b]{2}{*}{ Sig. } \\
\hline & & B & Std. Error & & & \\
\hline 1 & (Constant) & 2.347 & .309 & & 7.588 & .000 \\
\hline & AIS & .304 & .087 & .384 & 3.482 & .001 \\
\hline
\end{tabular}

$\mathrm{F}$-value $=12.121(0.002) \mathrm{R}=0.384 \mathrm{R}$-Square $=0.148$ Adjusted R-Square $=0.135$

Based on the results of Table 6, F-value is equal to 12.121, which is meaningful when the level of significance is one percent. This means there is a linear relationship between independent and dependent variable. In addition, t-values for both intercept and independent variable are statistically significant. The adjusted R-Square is equal to 0.135 which means the independent variable (AIS) can describe approximately $14 \%$ of the changes on commitment to accounting standards within corporate governance outcomes as dependent variable and finally the positive intercept indicates that a unit increase in AIS will have 0.304 unit increase on the effect of AIS on adding confidence and credibility to corporate governance outcomes.

\section{Discussion}

Current study aimed at examining the importance of AIS on outcomes of corporate governance from the perspective of auditors of financial managers and managers of the accounting department within the pharmaceutical industry in Jordan during the fiscal year 2019-2020. Quantitative methodology was embraced and total of (100) individuals were exposed to the tool of study (questionnaire). After application process (72) questionnaires were found to be properly filled and supported the study's eligibility to statistical analysis.

Results of study indicated the following:

- There is a good level of awareness regarding AIS applications and corporate governance as respondents held positive attitudes towards statements of study along with its variables.

- There is a good level of corporate governance commitment and AIS quality of information assurance within pharmaceutical industry in Jordan during the fiscal year 2019-2020.

- All study hypotheses were accepted and it indicated that all accounting governance variables were influential with differences in the influence level.

- The most influential variable of accounting governance appeared to be the variable of controlling as it scored an $R$ value of .534 and indicating that AIS applications control the quality and preciseness of accounting information which leads to better governance outcomes. 
- The least influential variable of accounting governance appeared to be commitment to accounting standards which scored the lowest $\mathrm{R}$ value .293 , but still indicating a positive influence of AIS applications on governance that is attributed to commitment to accounting standards.

Results of study indicated what was indicated earlier by Langfield-Smith (1997) when he reinforced the importance of AIS in an organization noting that AIS providers managers with the necessary information that aid in executing their roles and responsibilities in an efficient and effective way in areas such as decision making, performance evaluation, control, and planning. According to Langfield-Smith (1997), well-implemented AIS enable an enterprise to manage important information resources. It facilitates the efficient execution of business transactions arising from exchange of goods, and business transactions arising from collecting cost (i.e., internal transactions). It also facilitates cost accounting which provides information concerning material purchase. For Nobes and Stadler (2013), AIS improves decision making by improving the quality of information delivered in a timely manner. According to Nobes and Stadler (2013), quality information emanates from financial statements and accounting information systems. Quantitative and qualitative features of accounting information include compatibility, understandability, relevance, consistence, and timeliness.

Accounting information systems are in their content aim to improve the accounting image, and the financial image of the company, with a view to marketing to achieve good financial results, and therefore companies that are active in the financial markets in particular, prepare and present financial statements that show positive financial positions even if this does not reflect the real situation of the company. Here, such companies find themselves with two restrictions. The first limitation is the necessity to respect the legal rules in the transactions you make. As for the second limitation, it is necessary to give a positive image of the financial position, which may not reflect the real situation, in order to be able to compete.

Results of study also matched what came along with Wang and Huynh (2014) who demonstrated empirically that corporate governance is closely associated with management accounting. AIS are one of the primary tools used in management for internal control and planning by business enterprises, and Uyar and Kuzey (2016) seemed to agree with the same idea stating that many firms use AIS as an indispensable tool to make informed managerial decisions. It helps in setting targets and serves as a tool to limit the discretionary spending by managers. By limiting managers from misusing financial resources and better allocating resources, AIS contributes to corporate governance. Empirical studies have shown that prudent financial reporting and bookkeeping achieved using AIS impacts positively to corporate governance.

Thus it can be said that the merging between governance practices and applications of accounting information systems came in order to reduce negative results arranged on some of the negative accounting and governance practices that are represented in the production and presentation of misleading accounting information, which made it characterized by lack of credibility and therefore poor quality. . Thus, attention to corporate governance was precisely the interest in linking the relationship between governance as one of the managerial methods aimed at reducing administrative and accounting corruption, in general, and financial corruption in particular, and achieve the quality of accounting information. This is in view of the principles and components of governance, which is particularly in the disclosure and transparency of financial information, with what does internal and external oversight to fight corruption and guarantee the rights of parties involved in the company, especially shareholders. This leads to restoring investor confidence in the accounting and financial statements and reports.

\section{Conclusion and Recommendations}

The results of this study has indicated that AIS is of great importance in managing corporate governance and the characteristics are useful in decision making. AIS processes are useful accounting information that meets the decision makers' decision. The accounting information contained in AIS reflects summary and reports that reflect the principles of accounting. AIS and outcomes of corporate governance from perspective of auditors, from the perspective of auditors and others, AIS is important for corporate governance. It improves bookkeeping systems, financial reporting and budgeting systems.

\section{References}

Abraham, A., Deo, H., \& Irvine, H. (2008). What lies beneath? Financial reporting and corporate governance in Australian banks. Asian Review of Accounting, 16(1), 4-20

Agrawal, A., \& Cooper, T. (2017). Corporate governance consequences of accounting scandals: Evidence from top management, CFO and auditor turnover. Quarterly Journal of Finance, 7(01), 1650014.

Ahmed, K., \& Henry, D. (2012). Accounting conservatism and voluntary corporate governance mechanisms by Australian firms. Accounting \& Finance, 52(3), 631-662.

Baber, W. R., Gore, A. K., Rich, K. T., \& Zhang, J. X. (2013). Accounting restatements, governance and municipal debt financing. Journal of Accounting and Economics, 56(2-3), 212-227. 
Bolon, M. (1998). Factors influencing the alignment of accounting information systems in small and medium sized Malaysian manufacturing firms.

Borthick, A. F., \& Clark, R. L. (1990). Making accounting information systems work: An empirical investigation of the creative thinking paradigm. Journal of Information Systems, 4(3), 48-62.

Brown, P., Beekes, W., \& Verhoeven, P. (2011). Corporate governance, accounting and finance: A review. Accounting \& Finance, 51(1), 96-172.

Bukenya, M. (2014). Quality of accounting information and financial performance of Uganda's public sector. American Journal of Research Communication, 2(5), 183-203.

Carcello, J. V., Hermanson, D. R., \& Ye, Z. (2011). Corporate governance research in accounting and auditing: Insights, practice implications, and future research directions. Auditing: A Journal of Practice \& Theory, 30(3), 1-31.

Caskey, J., \& Laux, V. (2017). Corporate governance, accounting conservatism, and manipulation. Management Science, 63(2), 424-437.

Christensen, J., Kent, P., \& Stewart, J. (2010). Corporate governance and company performance in Australia. Australian Accounting Review, 20(4), 372-386.

Cong, Y., \& Freedman, M. (2011). Corporate governance and environmental performance and disclosures. Advances in Accounting, 27(2), 223-232.

Dănescu, T., Prozan, M., \& Prozan, R. D. (2015). Perspectives regarding accounting-corporate governance-internal control. Procedia Economics and Finance, 32(15), 588-594.

Evans, E., Burritt, R., \& Guthrie, J. (2011). Bridging the gap between academic accounting research and professional practice. Institute of Chartered Accountants in Australia.

Grossi, G., Steccolini, I., Biondi, L., \& Lapsley, I. (2014). Accounting, transparency and governance: the heritage assets problem. Qualitative Research in Accounting \& Management, 11(2), 146-164

Hancock, P., Howieson, B., Kavanagh, M., Kent, J., Tempone, I., \& Segal, N. (2010). Accounting for the future.

Honggowati, S., Rahmawati, R., Aryani, Y. A., \& Probohudono, A. N. (2017). Corporate governance and strategic management accounting disclosure. Indonesian Journal of Sustainability Accounting and Management, 1(1), 23-30.

Iskandar, D. (2015). Analysis of factors affecting the success of the application of accounting information system. International Journal of Scientific \& Technology Research, 4(2), 155-162.

Kadous, K., Koonce, L., \& Thayer, J. M. (2012). Do financial statement users judge relevance based on properties of reliability? The Accounting Review, 87(4), 1335-1356.

Kao, T. H. W. H. S. (2014). The effect of IFRS, information asymmetry and corporate governance on the quality of accounting information. Asian Economic and Financial Review, 4(2), 226.

Kılıç, M., Uyar, A., \& Ataman. B. (2014). Preparedness for and perception of IFRS for SMEs: evidence from Turkey. Accounting and Management Information Systems, 13(3), 492-519.

Komala, A. R. (2012). The influence of the accounting managers' knowledge and the top managements' support on the accounting information system and its impact on the quality of accounting information: A case of Zakat Institutions in Bandung. Journal of Global Management, 4(1), 53-73.

Leventis, S., Dimitropoulos, P., \& Owusu-Ansah, S. (2013). Corporate governance and accounting conservatism: Evidence from the banking industry. Corporate Governance: An International Review, 21(3), 264-286.

Magnan, M., \& Markarian, G. (2011). Accounting, governance and the crisis: is risk the missing link?. European Accounting Review, 20(2), 215-231.

Mamić Sačer, I., \& Oluić, A. (2013). Information technology and accounting information systems' quality in Croatian middle and large companies. Journal of information and organizational sciences, 37(2), 117-126.

Mashkour, S., \& Abbas, H. (2018). Corporate Governance System and the Quality of Accounting Information" A Contemporary Approach to Financial and Administrative Reform in Iraq: A practical study in a sample of public and private sectors, Conference of the Iraqi Association of Accountants and Auditors, Iraq.

Nobes, C., \& Stadler C. 2(013). How arbitrary are international accounting classifications? Lessons from centuries of classifying in many disciplines, and experiments with IFRS data. Accounting, Organizations and Society, 38, $573-595$.

Onaolapo, A., \& Odetayo, T. (2012). Effect of Accounting Information System on Organisational Effectiveness: A Case Study of Selected Construction Companies in Ibadan

Pallisserry, F. (2012). True and fair financial reporting: a tool for better corporate governance. Journal of Financial Crime, $19(4), 332-342$

Paulo, E., Pontes Girão, L. F. D. A., Carter, D., \& de Souza, R. (2013). The impact of the adoption of International Financial Reporting Standards on the quality of accounting information of the Brazilian and European public firms. David and de Souza, Rodrigo, The Impact of the Adoption of International Financial Reporting Standards on the Quality of Accounting Information of the Brazilian and European Public Firms (May 27, 2013).

Peters, G. F., \& Romi, A. M. (2014). Does the voluntary adoption of corporate governance mechanisms improve environmental risk disclosures? Evidence from greenhouse gas emission accounting. Journal of Business Ethics, 125(4), 637-666.

Rankin, M., Stanton, P., McGowan, S., Ferlauto, K., \& Tilling, M. (2012). Contemporary issues in accounting (1st Ed.). Australia: John Wiley \& Sons Australia, Ltd. 
Romney, M. B., \& Steinbart, P. J. (2006). Accounting Information Systems, 10th Edition

Seal, W. (2006). Management accounting and corporate governance: An institutional interpretation of the agency problem. Management Accounting Research, 17, 389-408

Susanto, A. (2017). The influence of accounting information system quality to accounting information quality and its implications to the good study program governance. Medwell Journals, 27, 5767-76.

Uyar, A., Kılıç, M., \& Gökçen, B. A. (2016). Compliance with IAS/IFRS and firm characteristics: evidence from the emerging capital market of Turkey. Economic Research-Ekonomska Istraživanja, 29(1), 148-16.

Uyar, A., Gungormus, A. H., \& Kuzey, C. (2017). Impact of the accounting information system on corporate governance: Evidence from Turkish non-listed companies. Australasian Accounting, Business and Finance Journal, 11(1), 9-27.

Wang, D. H. M., \& Huynh, Q. L. (2014). The role of corporate governance in the link between management accounting system and firm performance. Asian Journal of Finance \& Accounting, 6(1), 216-235.

Wilkin, C. L., \& Chenhall, R. H. (2010). A review of IT governance: A taxonomy to inform accounting information systems. Journal of Information Systems, 24(2), 107-146.

Wilkinson, J. W., Cerullo, M. J., Raval, V., \& Wong-On-Wing, B. (2000). Accounting information systems: Essential concepts and applications. New York: John Wiley and Sons

Wisna, N. (2015). Organizational culture and its impact on the quality of accounting information systems. Journal of Theoretical and Applied Information Technology, 82(2), 266.

Zhai, J., \& Wang, Y. (2016). Accounting information quality, governance efficiency and capital investment choice. China Journal of Accounting Research, 9(4), 251-266.

Zimmermann, J., \& Werner, J. (2013). Regulating Capitalism?: The Evolution of Transnational Accounting Governance. Springer.

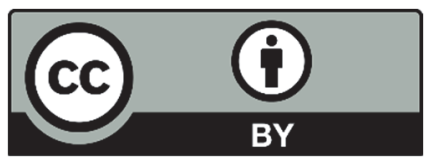

(C) 2021 by the authors; licensee Growing Science, Canada. This is an open access article distributed under the terms and conditions of the Creative Commons Attribution (CC-BY) license (http://creativecommons.org/licenses/by/4.0/). 